\title{
Article \\ Structural Failures Risk Analysis as a Tool Supporting Corporate Responsibility
}

\author{
Agnieszka Czajkowska ${ }^{1}$ and Manuela Ingaldi ${ }^{2, *(D)}$ \\ 1 Faculty of Civil Engineering and Architecture, Kielce University of Technology, al. Tysiąclecia Państwa \\ Polskiego 7, 26-540 Kielce, Poland; a_czajkowska@o2.pl \\ 2 Faculty of Management, Czestochowa University of Technology, al. Armii Krajowej 19b, \\ 42-201 Czestochowa, Poland \\ * Correspondence: manuela.ingaldi@wz.pcz.pl or manuela@gazeta.pl; Tel.: +48-34-32-50-426
}

Citation: Czajkowska, Agnieszka, and Manuela Ingaldi. 2021. Structural

Failures Risk Analysis as a Tool Supporting Corporate Responsibility. Journal of Risk and Financial Management 14: 187. https:// doi.org/10.3390/jrfm14040187

Academic Editor: Cristina Raluca Gh. Popescu

Received: 18 March 2021

Accepted: 15 April 2021

Published: 20 April 2021

Publisher's Note: MDPI stays neutral with regard to jurisdictional claims in published maps and institutional affiliations.

Copyright: (c) 2021 by the authors. Licensee MDPI, Basel, Switzerland. This article is an open access article distributed under the terms and conditions of the Creative Commons Attribution (CC BY) license (https:/ creativecommons.org/licenses/by/ $4.0 /)$.
Abstract: The problem of the structural failures is inextricably linked with the construction industry. A structural failure can be defined as the unintentional, violent destruction of a building object or its part, as well as structural elements of scaffolding, forming elements, sheet piling and excavation linings. Structural failures always entail financial and environmental losses that cause a big problem for companies. The analysis of the structural failures allows to indicate the causes that led to them, but also to introduce actions to help avoid them or decrease their appearance in the future. From the point of view of sustainability risk, human life, corporate responsibility, but also possible financial penalties, it is a very important element of the business process management in an enterprise. In the paper the structural failures occurring in Poland in 2015-2019 were analyzed based on data from the General Office of Building Control (GUNB). They are divided into two categories: caused by random factors and resulting from human error. Failures caused by human error were divided into those related to construction, used material and building operation (exploitation). The structural failures occurring during construction works, e.g., construction, renovation, demolition works, as well as in existing facilities, e.g., during the use of the facility but also in facilities excluded from use, were analyzed. Then, the individual causes of the structural failures were analyzed in terms of repeatability in each category. The risk priority number was calculated for the causes in the group "random events" and nine causes related to "human error". Actions aimed at reducing the risk of future failures were proposed. The results of the analysis provide conclusions that constitute input data for the improvement of both the processes themselves and the procedures for design, construction and exploitation, or methods and frequency of inspections.

Keywords: sustainability risks; quality management; corporate responsibility; structural failures

\section{Introduction}

Enterprises around the world become more socially responsible due to pressure from various stakeholders such as consumers, shareholders, local society, competitors and government (Yin 2017; Kong et al. 2021), but also because the social responsibility allows to build a long-term competitive advantage and relations with the enterprise's social environment, as well as with the aforementioned stakeholders. It consists of voluntary action for positive changes in the immediate social environment and the involvement of a person or organization in creating a better social reality.

Social responsibility plays an important role in the development and well-being of society. It is defined "as the ethical care and obligation that an individual in society pays to others mentally and sensuously, the ethical responsibility and feeling people have experienced that they should give to the society or others" (Zhang 2012; Suffari et al. 2019).

Corporate social responsibility (CSR) means generally to perceive the enterprise as an integral part of a socially responsible society, i.e., fulfilling specific obligations towards society. CSR activities as a result of globalization and internalization have proved that 
without them, a business may lose potential staff, value for employees and its attractiveness for society. Enterprises are forced to remain profitable and act responsibly at the same time (Chwistecka-Dudek 2016). Wołowiec (Wołowiec 2004) defines CSR as a philosophy of running a business that includes building stable, transparent relationships with all partners. In his opinion, the implementation of CSR leads to building a competitive advantage strategy based on ensuring lasting value for both shareholders and other partners—stakeholders. This means that the principle of competition focused on the interests (goals) of the owners should be replaced with the principle of social responsibility towards interest groups associated with the enterprise (Ingaldi and Klimecka-Tatar 2020).

From an operational management point of view, traditional non-CSR activities are less costly than CSR activities, but may be assessed negatively by public opinion (Bian et al. 2021). It should be remembered that being responsible does not only mean that enterprises meet all formal and legal requirements, but it is also associated with increased investment in human resources, in environmental protection and relations with stakeholders who may have a real impact on the effectiveness of the economic activity of these enterprises and their innovation. Therefore, this type of expenditure should be viewed as an investment and a source of innovation, and not only as a cost.

The concept of CSR is common and accepted by management practices around the world (Shilu Sun et al. 2020). It has become a well-established management element for various types of enterprises and organizations to solve social and environmental problems that pose a challenge to the modern world (Bhattacharyya 2010).

The reason why enterprises participate in CSR activities is to achieve sustainable development by improving competitiveness on market and improving the condition of the environment (Tang and Tang 2012). Engaging in activities for the benefit of local communities and natural environment, operating in accordance with the assumptions of social responsibility, is one of the assumptions of the sustainable development concept. Sustainable development means that the enterprise should establish cooperation with partners from the environment and find synergy between its interests and the interests of its social, economic and political partners, but also that it must derive economic benefits from these activities (Lazar et al. 2021).

The activities of enterprises should aim at the improvement of the quality of life and management of economic processes in a way which ensures the simultaneous minimization of the risk of interference with the natural environment. Where sustainability is not ensured, there can be negative consequences that can lead to ecosystem depletion or a variety of catastrophes (Oláh et al. 2019). Sustainable development strategies over the last two decades have focused on eco-efficiency, stakeholder involvement and social responsibility in the existing basic areas of the enterprise or organization's operations, i.e., the environmental side of the business has been the main focus. Today, enterprises face the challenge of going beyond eco-performance and developing breakthrough innovations that will directly address not only the problem of the environmental degradation, but also increasing inequalities in society (Šnircová Jana and Božiková 2016).

Risk management can be considered as the main driver of commitment to the sustainable development (Anderson 2005; Schulte and Hallstedt 2018). The sustainable risk has previously been defined as a risk arising from environmental or social justice issues, and numerous examples have highlighted how they can affect businesses at existential levels, both better and worse. There are many definitions of sustainability risk in the literature. Heinrich et al. claimed that it is ethical concerns related to environmental and socio-economic impacts of our business transactions and the reputational risks they may entail (Heinrich et al. 2010). According to Anderson, sustainability risk management deals with risks emanating from the environmental and corporate social responsibility areas (Anderson 2007). This means that each enterprise's activity should also be analyzed in terms of its impact on the natural environment and the local community, so that the enterprise can gain trust of its stakeholders (Ulewicz and Ulewicz 2020). 
Sustainability risk management (SRM) aims to improve awareness in three important areas: corporate risk as a threat and opportunity, risk management for corporate sustainable development, climate change and global warming, risk culture, the basic philosophy of the mentality "think globally, act locally." The framework of sustainability risk management in the enterprise provides guidance for managers on how to establish a holistic and systematic sustainability risk management process that generates the risk indicators, risk sources, targets and reporting systems needed to ensure that sustainability and threats are effectively addressed and improve the overall performance of the organization and its value (Yilmaz and Flouris 2010). SRM is a process that addresses and manages a broad spectrum of unknown and new threats to achieve sustainable value for long-term survival of the enterprise (Aziz et al. 2016).

There are many methods that can be used for risk analysis, including that related to sustainable development. Lindahl proposed to include environmental aspects in the Failure Mode and Effects Analysis (FMEA) (Lindahl 1999). This method allows for the determination of actions to minimize the risk of various types of problems (Yang et al. 2015). It is a technique that enables the identification of mistakes or problems and helps to eliminate or limit them. FMEA analysis is used to identify and assess the risk of potential mistakes, as well as their consequences. The method is based on analytical determination of the cause-and-effect relationships of potential defects and taking into account the criticality (risk) factor (Lolli et al. 2015; Wolniak 2019).

Construction enterprises deserve special attention in the fields of CSR and SRM. Unfortunately, this subject is often overlooked in the case of the aforementioned industry. What is more, it should be remembered that the construction industry has a very large impact not only on the economy, but also on the natural environment and local residents. It is up to the individual enterprise whether this impact will be positive or negative. It should be remembered that the constructed structures must be in harmony with the surroundings, not have too much impact on the flora, fauna and local community, they must be approved by this community and make it benefit from them in various ways.

The construction industry significantly contributes to the economic growth and social development of individual countries around the world (Boadu et al. 2020). Anaman and Osei-Amponsah (Anaman and Osei-Amponsah 2007) said that there is a significant relationship between the growth rate of the construction industry and the rate of macroeconomic growth in developing countries. Other economic sectors rely to a great degree on the construction industry; for example, the construction of production halls, office buildings, roads, infrastructure, water and power lines can increase the production of goods and services, while being an important means of increasing employment. That is why this sector is so important.

As mentioned before, the construction sector has a very large impact on the natural environment or the local community; unfortunately, sometimes it is also negative. This is related not only to the acquisition of materials, but also to the ever-larger areas intended for development. Depending on the type of facility which is constructed, this impact may be greater or smaller. In addition, an important issue is the occupational health and safety, because work in the construction sector is one of those with higher risk. Hence, it is important that this sector also takes into account the principles of sustainability risk and corporate responsibility in its operation. CSR and SRM activities in the construction sector should focus on two important elements, i.e., occupational health and safety, but also on sustainable construction and appropriately ecological buildings (Zhelykh et al. 2020). The policies of corporate social responsibility in the construction industry should set a good example in public procurement processes, set standards, and enforce the implementation of existing standards and regulations (Ulutaş Duman et al. 2016).

The development of various types of infrastructure and construction industry are essential for the proper economic development of the country, thus reducing the poverty of the community. However, it should be remembered that climate change may pose various 
types of threats to this infrastructure, especially during the construction and maintenance of sustainable infrastructure (Gilbert et al. 2020).

When designing or constructing various construction projects, different undesirable situations may occur, which are caused by various reasons, e.g., natural phenomena, sociopolitical conditions, due to technical reasons and due to the mistakes of inexperienced workers, etc. (Anthopoulos et al. 2013). Unwanted situations may also appear at the stage of exploitation of a given construction. Any undesirable situation may cause damage to the facility, which may result in delays in construction, higher construction costs, but also have a large impact on the natural environment and people (employees working during construction of the facility, people using it or living in the neighborhood). These undesirable phenomena are referred to in the literature as disasters, crises or failures (Loosemore 1999; Kerzner 2011). Therefore, it is worth analyzing such structural failures using many available techniques, while promoting uncertainty control and avoiding the risk of the structural failures to which a given structure is exposed.

The authors want to treat the subject of the structural failures comprehensively and analyze all their aspects. A construction disaster can be considered in social, financial and economic terms. As is known, a structural failure is an accident in which the rapid destruction of structural elements results in losses on many levels. It does not always involve loss of life, but it is always a big loss, for example financial. The connection of the risk of the structural failures with the safety of users, environmental impact and the financial aspect is the subject of research. The authors, by analyzing the structural failures, and in particular the causes and frequency of their occurrence, want to propose actions that will limit their occurrence or their influence in the future. The authors look for methods, the use of which can bring closer to the knowledge of the most common causes of the structural failures, which will allow to assess the risk of their occurrence and introduce monitoring, control and prevention measures. The limitation of the structural failures is associated with the increase of users' safety and meets the needs of sustainable construction.

The aim of the paper is to identify the main sources of risk of the structural failures and to propose actions that will reduce the risk of similar problems in the future. In the paper, the structure of the structural failures for 2015-2019 in Poland were analyzed, with particular emphasis on their causes, which allowed to identify the most frequently occurring ones. Next, with use of the risk analysis method (in this case Failure Mode and Effects Analysis-FMEA), the risk of occurrence of particular causes was determined and if needed the corrective actions were proposed, which could help to minimize their occurrence or minimize their effects in the future. This analysis was carried out for catastrophes caused by human errors, because in a certain sense people have an impact on their occurrence and their consequences and changing their behavior can have a positive effect in reducing the occurrence of certain structural failures.

\section{Framework for Construction Industry and Construction Risk Management}

\subsection{Structural Failures and Risk Analysis}

The development of various types of infrastructure has been defined as one of the sustainable development goals (SGDs) in the 2030 Agenda for Sustainable Development (United Nations General Assembly 2015), which proved the importance of a balance between new investment in infrastructure and sustainable development. It is necessary to understand the individual SDGs as a collective global development strategy with an international scope, but it must be undertaken primarily at the regional level, hence the importance of construction industry and new investments (Surówka et al. 2021). It should be kept in mind that the quality of life of inhabitants, both in large agglomerations and in small rural areas, depends to a large extent on the existence of technical, economic and social infrastructure (Surówka et al. 2021).

Buildings and structures, and various types of infrastructure are therefore important to achieving the SDGs for different main reasons (Kloosterman et al. 2020) and must meet local needs in a sustainable and environmentally friendly manner (Choguill 1996). 
Sustainable development focuses on creating or maintaining natural areas to survive for generations to come; it involves creating added value between different areas, potentially allowing cooperation and the exchange of experiences between other isolated areas, and also underlines the importance of rural areas. Technical infrastructure has been recognized as the main instrument for the implementation of the sustainable development strategy (Surówka et al. 2021).

Sustainable infrastructure supports the buildings, engineering and infrastructure that are essential to the survival of society (Boyle et al. 2010). This is why sustainable infrastructure matters most to human, economic and land welfare, including consideration of natural hazards (Padgett et al. 2009; Thomé et al. 2016).

One of the elements that must be taken into account in sustainable infrastructure are structural failures. Of course, this approach takes into account the minimization of their occurrence, as well as the impact on the natural environment or people (employees, users or local residents). However, in order to do so, a thorough analysis of such structural failures is needed from the point of view of their occurrence, but also from the point of view of the associated risk.

The analysis of the causes of the structural failures should begin with the definition of a structural failure. According to Article 73 of the Construction Law, a structural failure means unintentional, violent destruction of a building or its parts and structural components of scaffolding, shape-forming components, sheet piling and excavation support (Act 1994; Bąk and Chmielewski 2019; Czajkowska 2019). The problem of the structural failures is inextricably linked with the construction industry. The analysis of the causes of their occurrence is aimed at the improvement of those links in the construction processdesign, construction and exploitation-which have failed. The results of the analysis give conclusions that constitute input data for the improvement of both the processes themselves and the procedures for design, construction and exploitation, as well as the methods and frequency of inspections.

The structural failures resulting from random causes are considered a group that cannot be comprehensively controlled; what is more, they are more unpredictable. However, this does not mean that preventive action cannot be taken. The results of analyses of the structural failures caused by random causes are the basis for introducing changes in the assumption of loads in the design of buildings, which is currently mentioned in the PN-82/B-02000 standard (PN-82/B-02000). Climate change and the weather anomalies observed for several decades, which cause stronger rainfall or snowfall and hurricane winds, make it necessary to introduce changes in the design principles. Most often, objects are designed for a basic load combination. The European standard PN-EN 1991-1-4:2008 and the changes introduced to the standard PN-77/B-02011/Az1:2009 tighten the requirements for the design of buildings subject to wind loads (Szymczak-Graczyk 2011).

In July 2009, the change Az1 was introduced to the standard PN- 77/B-02011. It consisted of the introduction of a new map of Poland's division into wind load zones, new characteristic values of wind speed and pressure of this speed, correction of the exposure factor and increasing the value of the load factor (Szymczak-Graczyk 2011). The roofs of buildings, in addition to their own weight, must bear snow, wind and technological loads. The roof structure and its covering must be designed in such a way as to meet the first limit of state-bearing capacity and use. Constructions work as a whole and its individual parts must be fit for their intended use, with particular regard to the health and safety of those who come into contact with them throughout their life cycle (Blikharskyy et al. 2020). Haigh et al. (Haigh et al. 2006) proposed to conduct research on the structural failures in order to improve the life of building objects, but also to consider the need to anticipate, evaluate, prevent, prepare, respond and recover from breakthrough challenges.

Risk analysis is a process, the elements of which are identification, estimation and hierarchization of individual events (problems, circumstances) that may adversely affect the achievement of a specific goal (Dziwiński 2009). The concept of risk is closely related to the concept of "risk management" and denotes activities related to risk mitigation and 
protection against its effects. It is a method of identifying and then controlling areas or events that may lead to undesirable changes or effects.

Different authors (May 2014; Deptuła and Knosala 2015) distinguish three stages of risk management: risk identification; risk assessment and measurement; risk monitoring and control. In the process of managing the risk of the structural failures, the authors distinguished four stages of this process: identification; classification; measurement; monitoring and response methods (Figure 1).

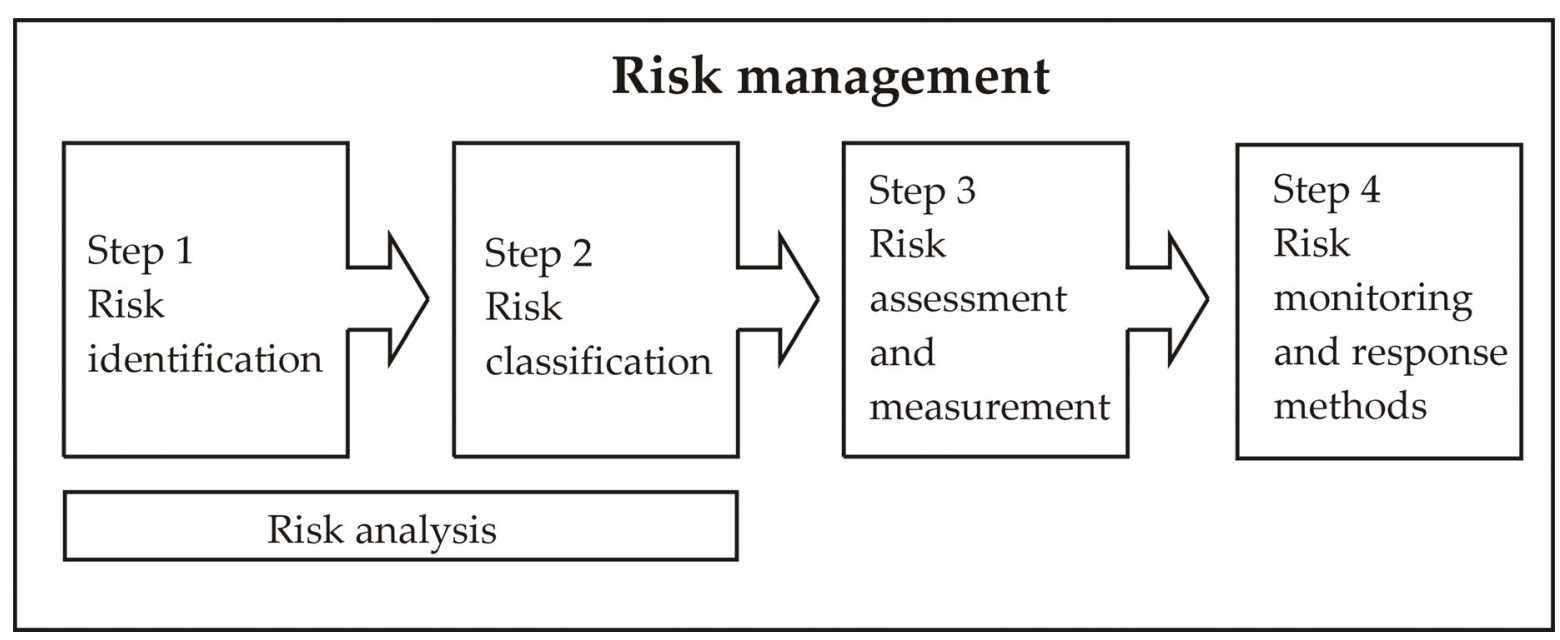

Figure 1. Risk management stages (own study based on (May 2014; Deptuła and Knosala 2015)).

The individual stages of risk management can be used to analyze the risk of the structural failures. These stages were used in this paper as follows:

Step 1. Risk identification - the threats were identified on the basis of the analysis of annual reports of the General Office of Building Control (GUNB). The data were presented on radar charts and analyzed in detail.

Step 2. Hazard classification-classification was made on the basis of the causes of the structural failures. Two main groups were distinguished-disasters caused by random causes (mainly due to the force of nature) and those caused by man (human errors). The failures from the second group (human errors) were classified into three subgroups closely related to the life cycle of a building, namely-design, construction and exploitation.

Step 3. Risk assessment and measurement-based on the FMEA method, and more precisely on the determination of the probability of a given threat $(\mathrm{P})$, severity of its result (S), difficulties in its detection (D). These data made it possible to determine the Risk Priority Number (RPN). This number indicates which of the threats (causes) identified in steps 1 and 2 are the most critical from the point of view of the structural failures.

Step 4. Risk monitoring and response methods-in the fourth stage, so-called countermeasures (preventive actions), i.e., actions which introduction is aimed at reducing the risk of the structural failures in the analyzed groups of causes, are taken.

As mentioned before, the Failure Mode and Effects Analysis (FMEA) method was used to analyze the process of managing the risk of the structural failures. The FMEA method was introduced in the late 1940s by the armed forces of the United States. In the 1960s, it was used in the aerospace industry as a design methodology for reliability. This method can be used to analyze various products and processes in many industries such as the automotive, aviation and electronics industries (Yang et al. 2015; Muzakkir et al. 2015; Su et al. 2014; Bhattacharjee et al. 2020). The detailed methodology of FMEA analysis is presented in Section 3. Materials and methods. 


\subsection{Requirements for Construction Objects}

For normal maintenance, construction works must meet the requirements of Annex 1 included in Regulation (EU) No 305/2011 of the European Parliament and of The Council (Regulation 2003, 2010, 2011, 2019). Requirements for construction objects during an economically justified period of use are presented in Figure 2.

\section{The scope of the requirements for construction}

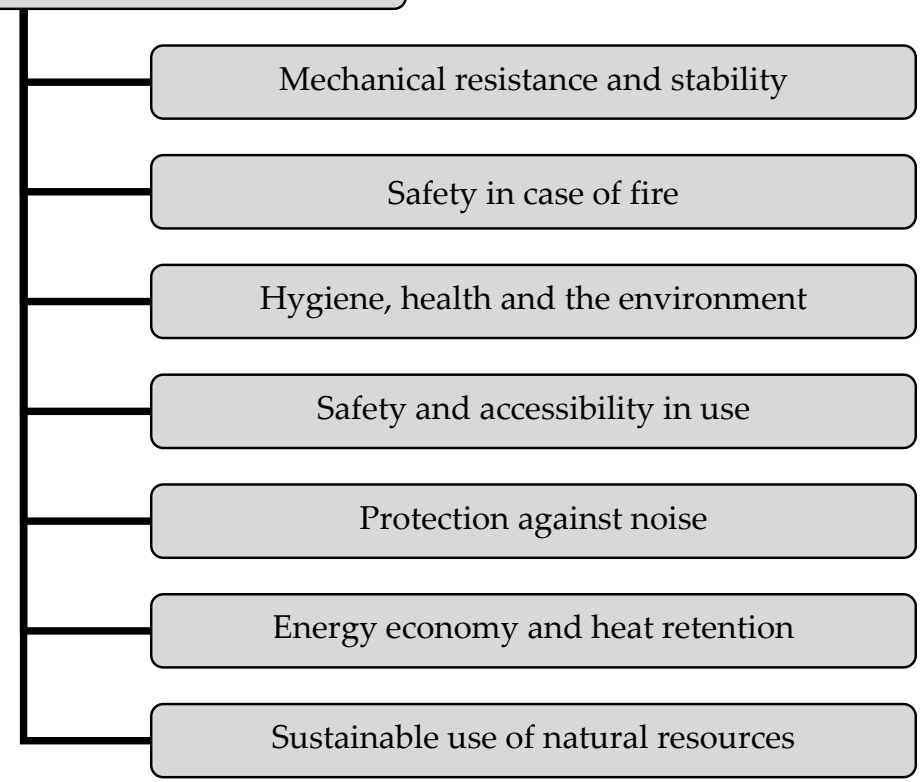

Figure 2. The scope of the requirements for construction objects (Regulation 2011).

1. Mechanical resistance and stability

The design and construction of the facility must take into account the loads that, both during construction and exploitation will not lead to collapse of the whole or part of the facility; major deformations to an inadmissible degree; damage to other parts of the facility or its equipment; damage by an event to an extent disproportionate to the original cause.

2. Safety in case of fire

The design and construction of the facility must assume the risk of a fire breakout. Buildings must be designed in such a way that the load-bearing capacity of the structure is maintained for some time during a fire. The designer and contractors are obliged to meet the technical and construction requirements relating to fire protection. The design, taking into account the possibility of a fire, must ensure restrictions on the spread of fire and smoke in the building and to other objects, the possibility of evacuating people at risk, the safety of rescuers.

3. Hygiene, health and the environment

The facilities must not pose a threat to employees, users or neighbors throughout their entire life cycle. They must not emit harmful volatile, aqueous or solid substances in any way.

4. Safety and accessibility in use

The facilities must be safe for its users. There must be no risk of falls, burns or electric shock. Moreover, public utility buildings must ensure safe use for people with disabilities.

5. Protection against noise

Protection against noise is one of the seven basic requirements. People want to live quietly, have a quiet neighborhood and work quietly. Unnecessary noise is distracting, stressful and a 
source of discomfort. In Poland there are many standards and regulations (PN-B-02151-4:201506; PN-EN-12354-1:2017-10; PN-B-02151-5:2017-10) that deal with the acoustic requirements of building materials and the buildings themselves.

\section{Energy economy and heat retention}

It is very important to equip buildings ensuring energy economy and heat retention. Optimum energy consumption also applies to the construction and demolition phase.

\section{Sustainable use of natural resources}

Throughout the life cycle of the facilities (design, construction, demolition), it is important to ensure sustainable use of resources (sustainable design), sustainable construction and sustainable demolition. Sustainable design includes the reduction of energy, water, raw materials, greenhouse gas emissions and waste production (Czajkowska and Ingaldi 2019). There are many ways to reduce the negative impact on the environment in the construction industry. One of the solutions is use of passive houses, energy-efficient houses, the use of safe building materials, modernization of heating systems, recycled materials, etc.

\section{Materials and Methods}

In the study, the level and causes of the structural failures in 2015-2019 were analyzed. The analysis was made based on data from the General Office of Building Control (GUNB). The data concerned the structural failures registered throughout Poland.

During the analysis, the individual causes of the structural failures were classified, and its results were presented on radar charts, perfectly presenting the level of occurrence of each cause in particular years. These charts presented the results of the quantitative data. This analysis allowed to indicate which causes of structural failures were the most common.

The aim of the analysis presented in the paper was also to propose some preventive actions that would help to reduce the frequency of the structural failures in the future. Risk analysis was used for their implementation. The individual causes of structural failures were analyzed in terms of repeatability in each category. In this case the structural failures cause by man (human errors) were analyzed because these are causes that people have an influence on. Actions aimed at reducing the risk of future failures were proposed.

In accordance with the methodology of the FMEA, the main causes of risk (threats) that may cause the structural failures have been identified. Each threat was assessed according to its probability of occurrence $(\mathrm{P})$, severity $(\mathrm{S})$ and detection $(\mathrm{D})$. The risk priority number (RPN) was calculated according to the formula Yang et al. 2015; Muzakkir et al. 2015; Su et al. 2014; Bhattacharyya 2010; Bhattacharjee et al. 2020)

$$
\mathrm{RPN}=\mathrm{P} \cdot \mathrm{S} \cdot \mathrm{D}
$$

where:

$\mathrm{P}$-probability coefficient, specifying the frequency of occurrence of the structural failure associated with a given risk, on a scale from 1 to 10 , where 1 means no occurrence, and 10 - occurrence in each production cycle;

S-severity coefficient, which determines how serious the given risk of the structural failure is, on a scale from 1 to 10 , where 1 means negligible importance, and 10-very high; $\mathrm{D}$-detection coefficient, which determines the degree of difficulty in counteracting the occurrence of a given type of the structural failure (early detection of the cause), on a scale from 1 to 10, where 1 is an easy possibility to counteract, and 10-a very difficult one.

The risk priority number (RPN) may vary from 1 to 1000 . The higher the RPN value is, the greater the risk associated with the threat is.

It should be noted that the main causes of the structural failures correspond to all stages of the investment process-from investment planning (design of building), through its implementation (construction), to operation (use). The fact that all these aspects are affected by the structural failures means that every step of the process needs to be controlled. Identification of the most common causes will also allow to take appropriate, directly 
targeted preventive actions. The FMEA method was carried out for the following stages of the life cycle of constructions: design, construction and exploitation (Figure 3).

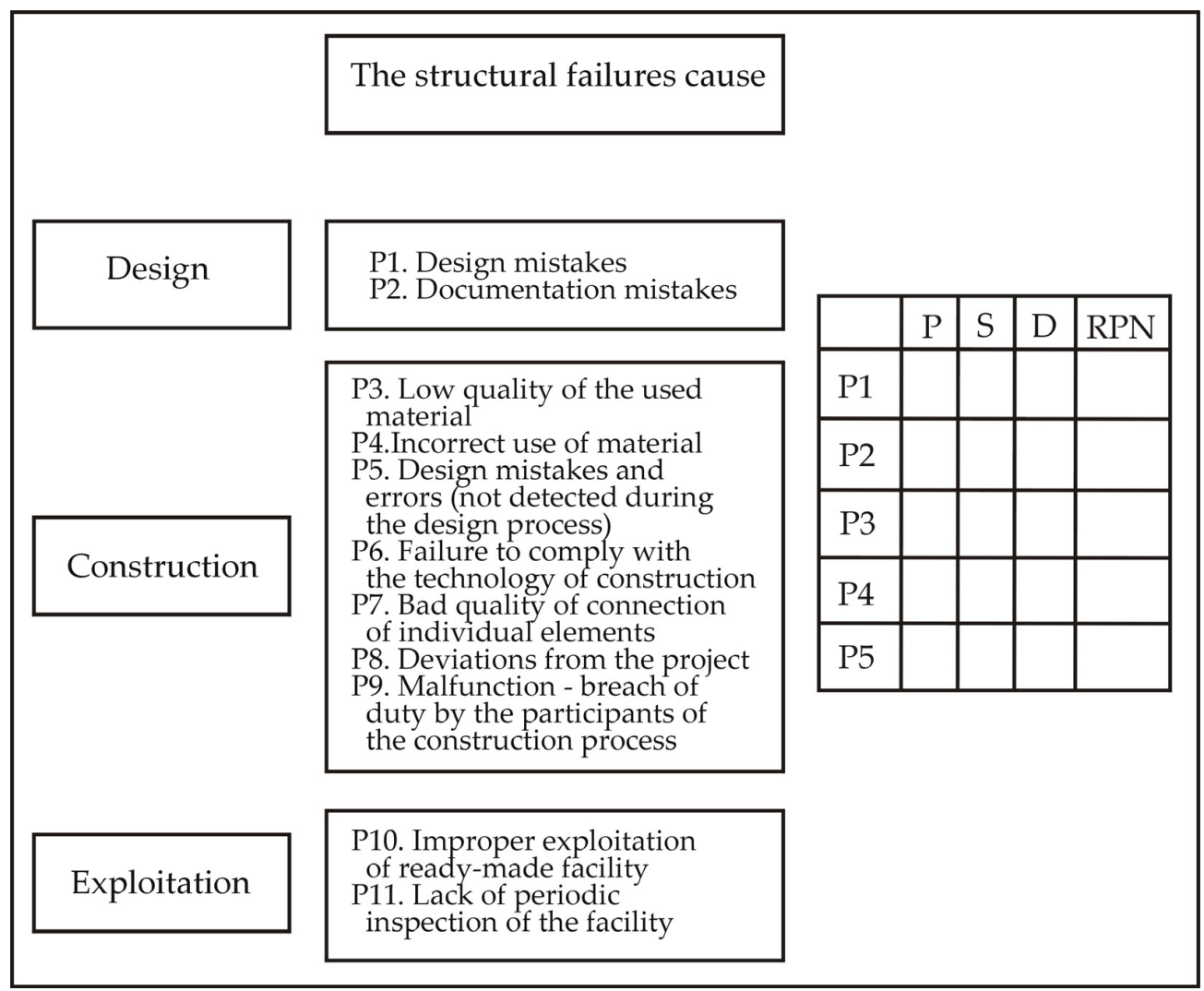

Figure 3. FMEA in structural failures analysis (own study).

\section{Results}

\subsection{Causes of Structural Failures}

The causes of structural failures can be divided into two groups-those caused by random factors (random causes), such as wind, snow, storms, etc., and those caused by man (resulting from human error). The second group includes both incorrect actions and negligence. Structural failures directly related to human activity occur at every stage of the life of a building object, i.e., design, construction and exploitation. Unnoticed design errors can become visible when it is too late to revise. The use of materials of too-low quality results in serious problems both in the construction and exploitation phases. Its effects can be very severe. During the exploitation, it is important to observe and carry out periodic inspections and repairs when necessary.

The number of structural failures in the last five years ranged from 244 in 2019 to 605 in 2017. The main causes of structural failures are random causes and those caused by man. There are many more failures due to random causes than those caused by man. The largest number of structural failures resulting from random causes was recorded in 2017, and the lowest in 2018. Regarding structural failures caused by man, they were the most numerous in 2017 (69), and the least numerous in 2019 (52). Strong winds are the main cause of structural failures amongst the random causes. Over the years, it can be noted that fewer causes of structural failures are mistakes made during the construction process, and more often they are caused by random causes that are often impossible to predict. The basic classification of the structural failures with their most frequent causes is presented in Figure 4 . 


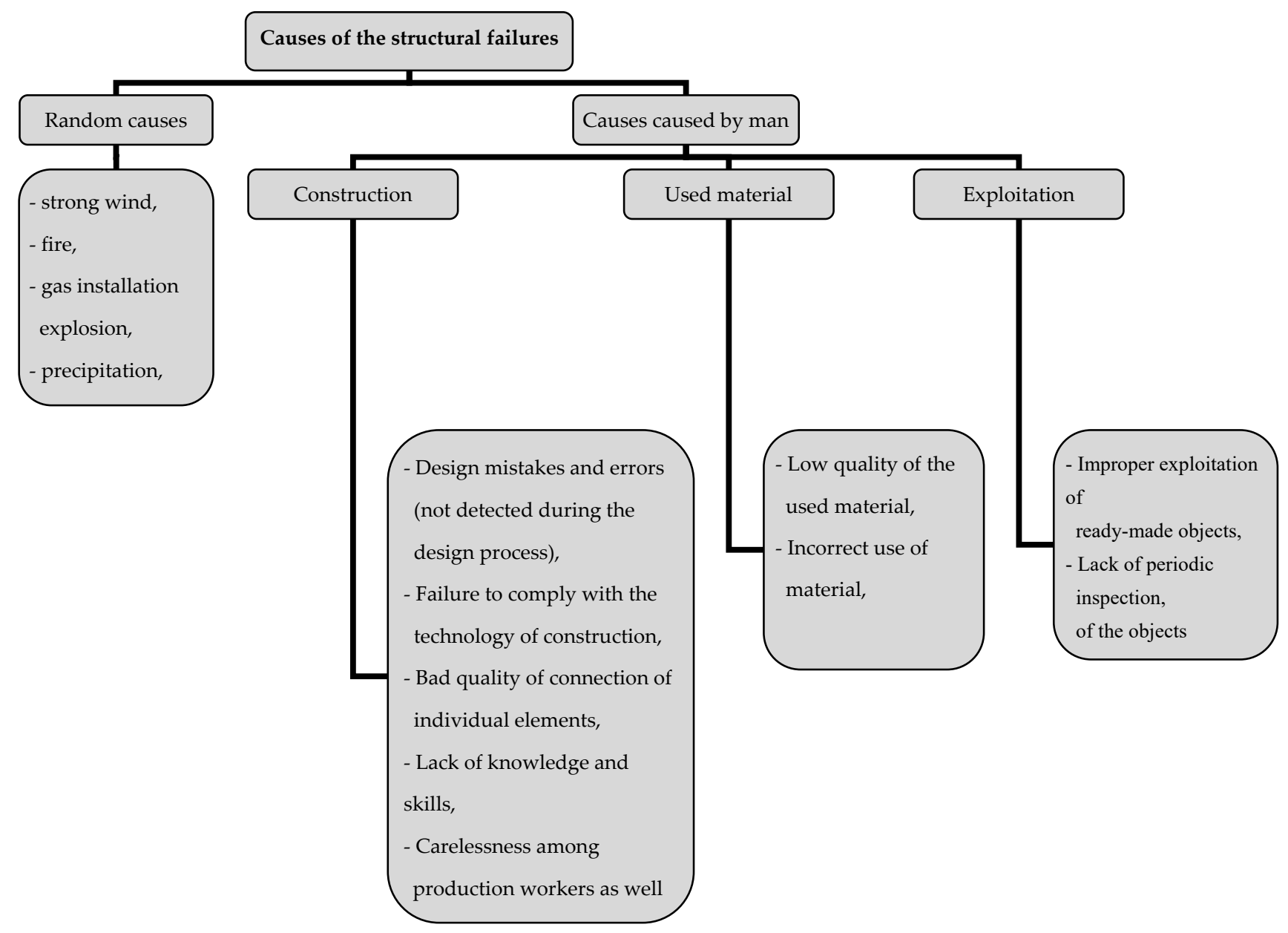

Figure 4. Classification of structural failures (own study).

Although the numbers of the structural failures do not seem very high, it is important to remember what effects they can cause. There are huge financial losses associated with expenses that must be paid. These costs include not only the financial loss in the form of a damaged facility (the cost of its design and construction), but also the costs incurred after the failure, i.e., analysis of the cause of a given structural failure, possible compensation, removal of the consequences of the failure (cleaning the area), possible cost of reconstruction of the damaged facility if such an action is planned, etc.) Often, many people die because of such structural failure, for example; on 14 August 2018, in Genoa, Italy, 43 people died during the collapse of a viaduct; a loss which cannot be converted into monetary value. Yet human life cannot be converted into an amount of money, it is a moral loss which cannot be replaced.

\subsection{Analysis of the Structure and Causes of the Structural Failures in 2015-2019}

At the beginning, the structural failures in 2015-2019 were analyzed depending on the type of facility that had suffered the failures: residential buildings, farm or livestock buildings, other construction facilities, public utility facilities, warehouse buildings, buildings for individual recreation, collective residence buildings, industrial facilities, industrial facilities and other construction facilities. As previously mentioned, all the data on the number of the structural failures come from the reports of the General Office of Building Control (GUNB). These data are presented in Figure 5a,b. The data of this analysis, as well as the following ones, are divided into two separate figures due to the large differences in the number of failures. 
(a)

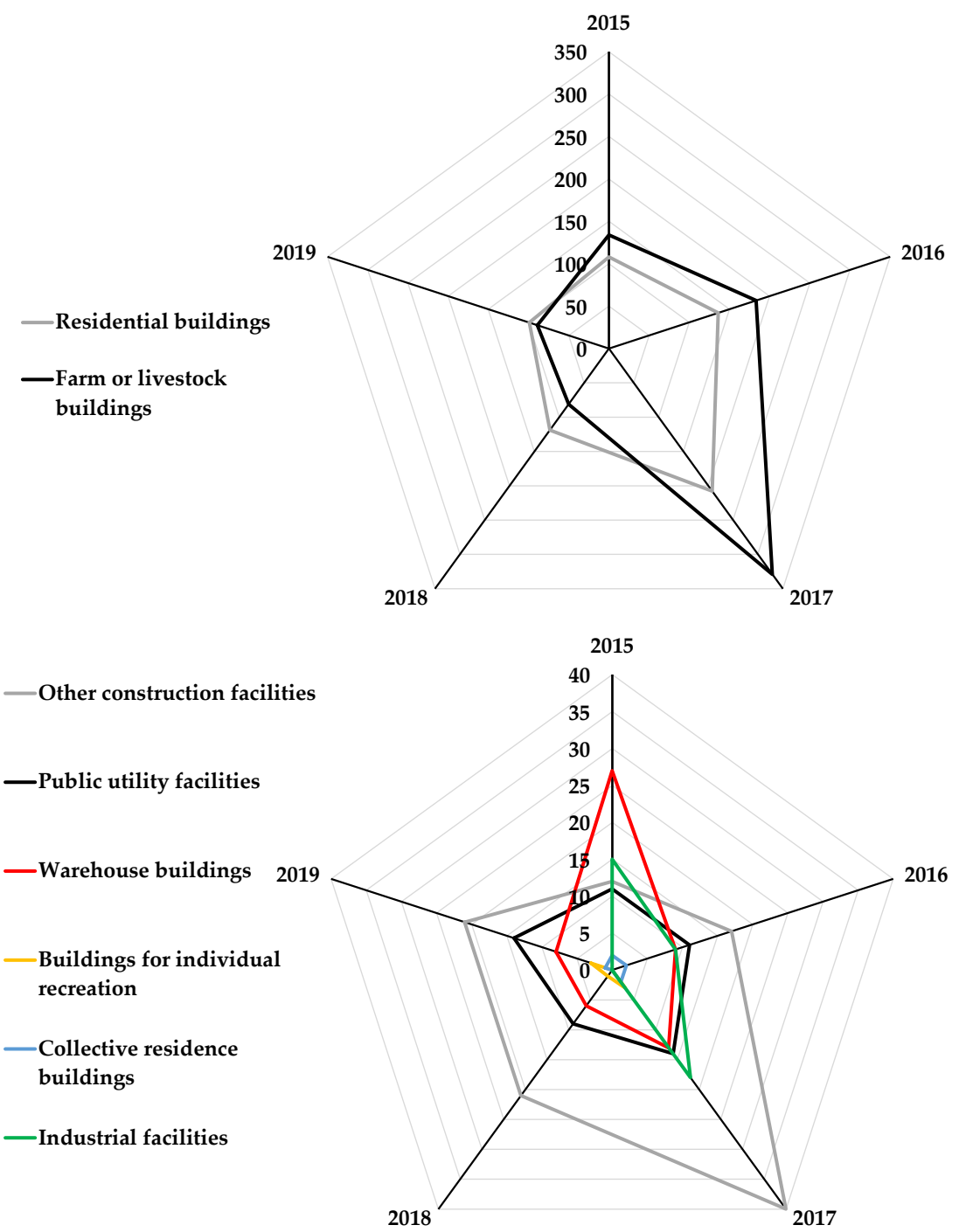

Figure 5. Analysis of the structural failures by type of facility in which the failure occurred (a) part 1; (b) part 2 (own study).

The analysis of the chart showed that most structural failures concerned farm or livestock buildings (Figure 5a). Their greatest number was 329 in 2017, and the lowest in 2019-89. The structural failures in residential buildings are in second place in terms of occurrence. Here also, the greatest number of failures was recorded in 2017 (208) and second greatest in 2016 (136). Public utility facilities experienced failures in the analyzed period, on average, from 9 in 2018 to 14 in 2017 and the same number of times in 2019 (Figure 5b). Warehouse buildings faced failures between 6 times in 2018 and 27 in 2015. Buildings for individual recreation occasionally suffered from the failures in the analyzed period (from one to three times a year), similarly to collective residence buildings. Among industrial facilities, 9 facilities faced failures in 2016, 15 facilities in 2015 and 18 facilities in 2017.

An important element of the analysis of the structural failures is to find their causes in order to limit their occurrence in the future. The first and most important types that were mentioned earlier are random causes and causes resulting from human errors (caused by man). The number of the structural failures, with their classification into those caused by random causes, mistakes during maintenance, mistakes during the construction of a new facility or performing other construction works in an existing facility, and mistakes in documentation of the facility in 2015-2019 are presented in Table 1. There are many more failures due to the random causes than there are failures caused by man. The significant 
difference between the failures due to random causes over those resulting from direct human error and human negligence made it necessary to present the results of their analysis additionally in two separate figures (Figure $6 a, b$ ), which better visualizes the frequency of their occurrence.

Table 1. Structure of the causes of structural failures in the period 2015-2019 in Poland (own study).

\begin{tabular}{cccccc}
\hline Causes & $\mathbf{2 0 1 5}$ & $\mathbf{2 0 1 6}$ & $\mathbf{2 0 1 7}$ & $\mathbf{2 0 1 8}$ & $\mathbf{2 0 1 9}$ \\
\hline Random causes & 242 & 313 & 536 & 177 & 189 \\
\hline Mistakes during maintenance of a facility & 38 & 39 & 42 & 44 & 33 \\
\hline $\begin{array}{c}\text { Mistakes during construction of a new facility or } \\
\text { performing other construction works in an existing facility }\end{array}$ & 19 & 8 & 26 & 16 & 22 \\
\hline Mistakes in documentation of the facility & 1 & 2 & 1 & - & - \\
\hline
\end{tabular}

(a)

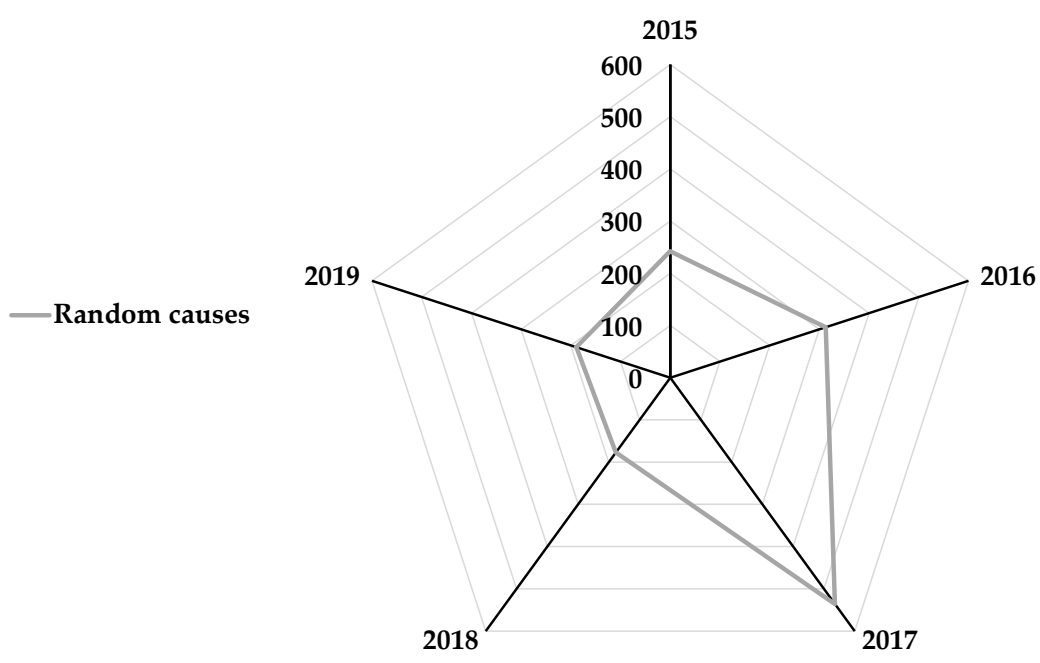

(b)
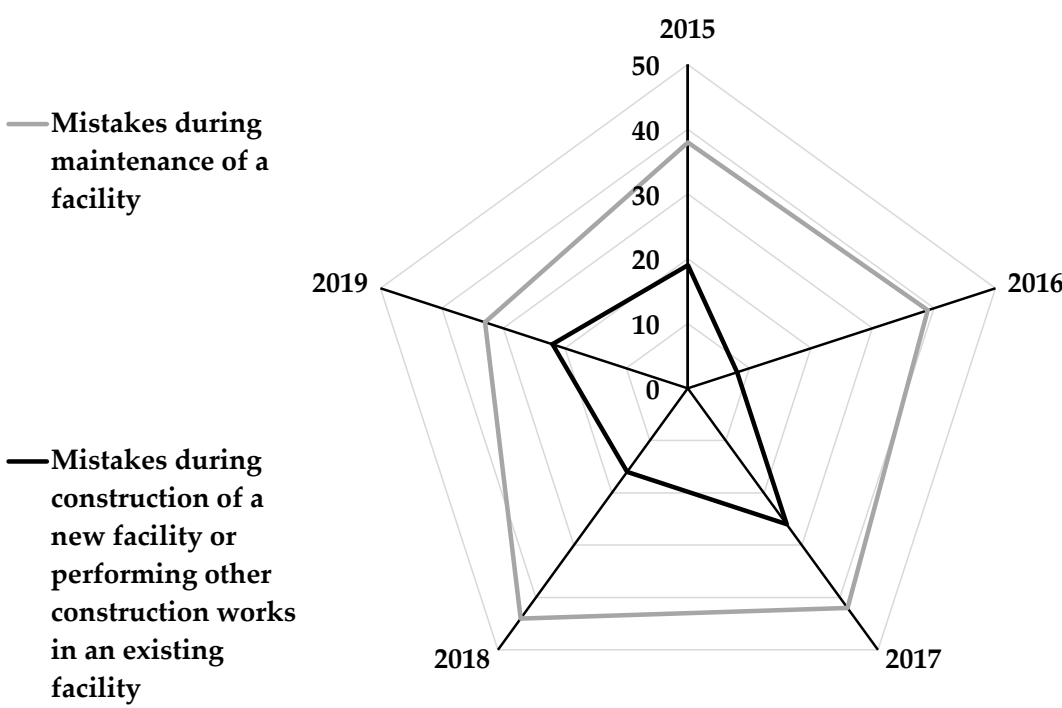

Figure 6. Structure of the causes of structural failures in the period 2015-2019 in Poland (a) part 1; (b) part 2 (own study).

The largest number of structural failures due to the random causes was in 2017 and the lowest in 2018. As it can be seen in the presented graphs (Figure 6), random causes in 
2017 were responsible for the occurrence of the structural failures 12 times more often than mistakes during maintenance. The mistake rate during maintenance during all five years is very similar, and varies from 33 disasters in 2019 to 44 in 2018 (Figure 6b).

The analysis presented in Figure 6b showed that the structural failures in 2015-2019 more often result from human errors made during maintenance of a facility than during the construction of a new facility or performing other construction works in an existing facility.

\subsection{Analysis of the Causes of the Structural Failures Resulting from Human Error (Caused by Man)}

The results of the research showed that most structural failures are caused by forces of nature, i.e., wind, snow. As the name suggests, they result from so-called unforeseen causes, i.e., floods, winds, climate changes, weather anomalies. People have no direct influence on them, but their analysis provides information that is the basis for introducing changes in the assumption of loads in the design of buildings or planning long-term remedial measures.

The authors analyzed the causes of structural failures related to inappropriate action or negligence of man. They can be classified into three groups:

1. mistakes during maintenance of a facility;

2. mistakes during construction of a new facility or performing other construction works in an existing facility;

3. mistakes in documentation of the facility.

Among the causes of the structural failures during maintenance of the facility, the following causes can be mentioned in particular:

- $\quad$ poor technical condition of the facility;

- lack of inspection of the facility;

- failure to take the required actions by the owner or manager resulting from the inspection of the facility;

- $\quad$ use of the facility contrary to its intended purpose;

- failure to take required actions by the owner or manager resulting from other technical documents;

- failure to perform the required obligations by the owner or manager resulting from the actions of construction supervision authorities;

- $\quad$ other circumstances.

The causes of the structural failures occurring during maintenance of the facility are presented in Figure 7. Due to the large differences in numbers of individual causes, Figure 7a,b was prepared for improved clarity.

The data analysis showed that the most common cause of structural failures in 20152019 was poor technical condition of the facility. In 2018, this resulted in 35 structural failures. In second place is lack of inspection of the facility, which is responsible for 6-19 failures per year.

Mistakes during construction of a new facility or performing other construction works in an existing facility are the following:

- failure to comply with the technology of construction;

- malfunction-breach of duty by the participants of the construction process;

- deviation from the project;

- $\quad$ other circumstances.

The causes of structural failures in a group associated with mistakes during construction of a new facility or performing other construction work in an existing facility are presented in Figure 8. In this group, the most common cause of structural failures is failure to comply with the technology of construction. This cause was responsible for 20 failures in 2017. Malfunction-breach of duty by the participants of the construction process is in second place, as it resulted in 14 failures in 2017. 
(a)

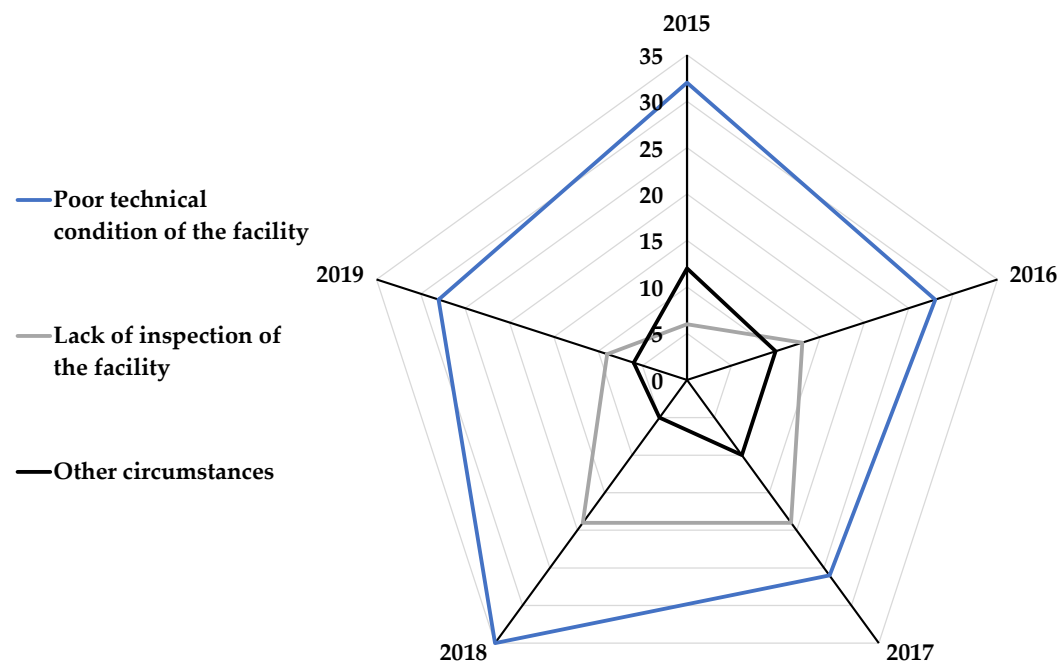

(b)

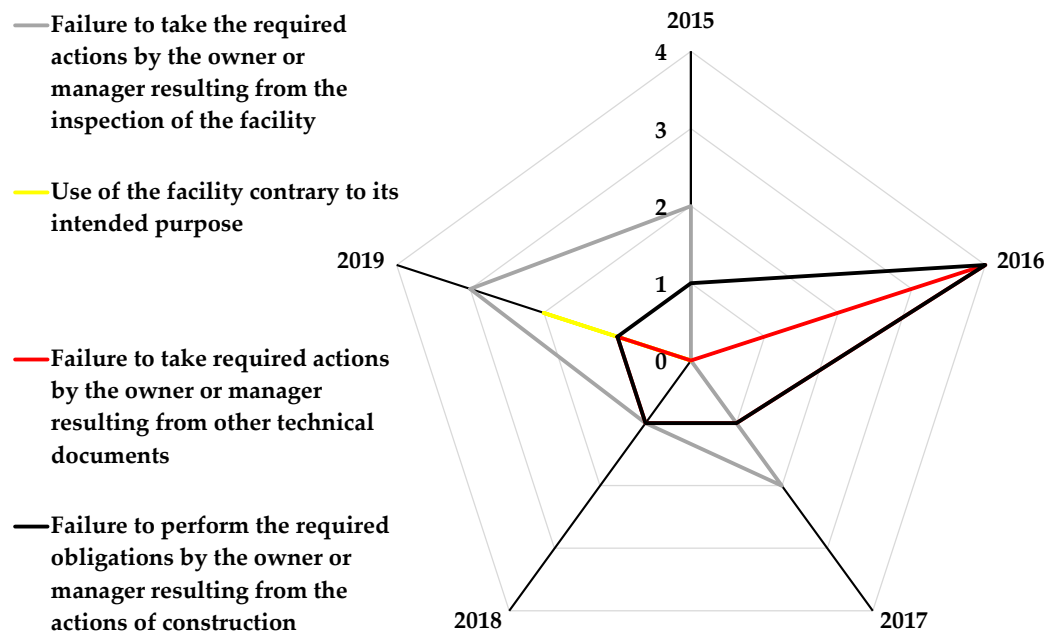

supervision authorities

Figure 7. Causes of the structural failures occurring during maintenance of the facility (a) part 1; (b) part 2 (own study).

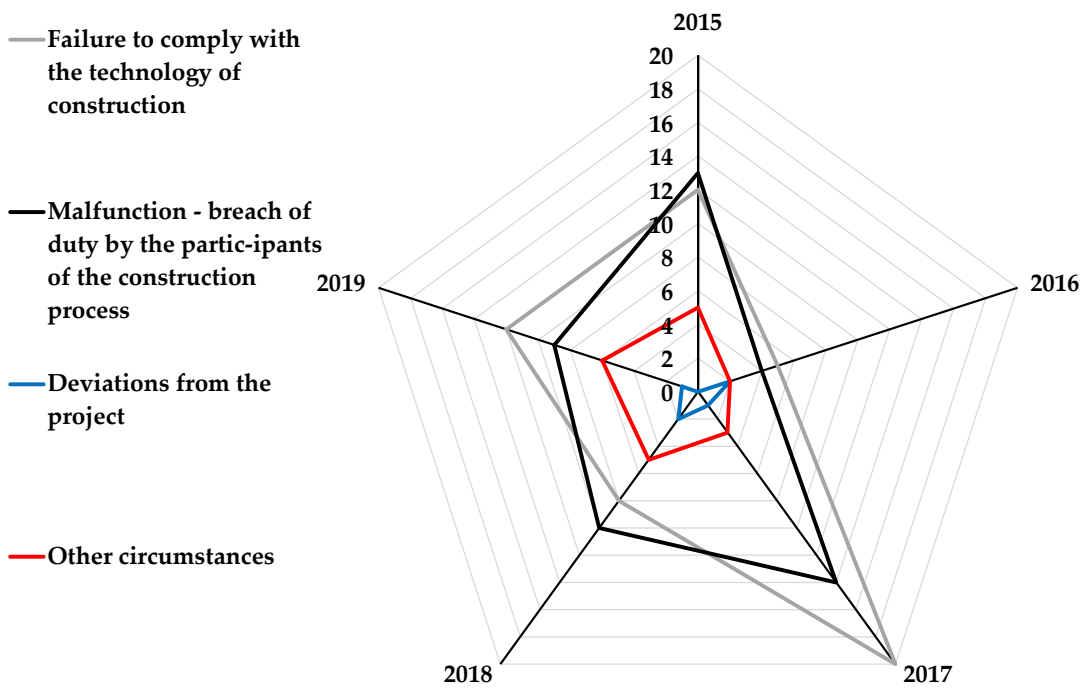

Figure 8. Structure of the causes of the structural failures during construction of a new facility or performing other construction works in an existing facility (own study). 


\section{Discussion}

In the case of the structural failures, the risk results from random causes (weather anomalies, climate change), as well as human fault, i.e., exceeding competences, failure to control or unreliable control by the entities required to do so, saving on materials and, finally, failure to undertake actions in the event of the occurrence of conditions for the occurrence of a catastrophe hazard (no repairs). The greatest penalty is the structural failures resulting in temporary or permanent damage to health, sometimes even death.

The causes of structural failures as risk factors can be considered during individual stages of the investment process, during which a failure may occur, namely, design, construction and exploitation. The analysis shows that design mistakes and documentation mistakes are relatively rare. Perhaps this is due to numerous analyses and assessments of project documentation. Most often, however, it is possible to deal with negligence during the construction process and during the exploitation of finished buildings. Often, the structural failures of the residential buildings are due to the lack of control during their exploitation.

For the causes of structural failures resulting from human error, risk assessment and analysis according to the FMEA method were used. This method is described precisely in Section 3. The purpose of the risk assessment and analysis of the structural failures is to propose actions aimed at preventing their occurrence or to minimize their effects in the future. The results of the analysis are presented in Table 2.

Table 2. Results of FMEA for the structural failures caused by human error (own study).

\begin{tabular}{|c|c|c|c|c|c|c|c|}
\hline Stage & Cause of the Structural Failure & No & $\mathbf{P}$ & $\mathrm{S}$ & D & RPN & Preventive Actions \\
\hline \multirow{5}{*}{ Design } & Design mistakes & P1 & 1 & 10 & 9 & 90 & - \\
\hline & Documentation mistakes & $\mathrm{P} 2$ & 1 & 10 & 9 & 90 & - \\
\hline & Low quality of the used material & P3 & 5 & 10 & 9 & 450 & $\begin{array}{l}\text { Regulations including the minimum } \\
\text { parameters with which the material must } \\
\text { comply }\end{array}$ \\
\hline & Incorrect use of material & $\mathrm{P} 4$ & 3 & 9 & 9 & 243 & $\begin{array}{l}\text { Controls at the construction stage of a } \\
\text { new facility }\end{array}$ \\
\hline & $\begin{array}{l}\text { Design mistakes and errors (not } \\
\text { detected during the design process) }\end{array}$ & P5 & 2 & 10 & 8 & 160 & - \\
\hline
\end{tabular}

$\begin{array}{ccccccccc}\text { Construction } & \begin{array}{c}\text { Failure to comply with the technology } \\ \text { of construction }\end{array} & \text { P6 } & 6 & 8 & 7 & 336 & \begin{array}{l}\text { unprofessional actions of all participants } \\ \text { of the investment process } \\ \text { Controls at the construction stage of a } \\ \text { new facility }\end{array}\end{array}$

\begin{tabular}{ccccccccc}
\hline $\begin{array}{c}\text { Bad quality of connection of individual } \\
\text { elements }\end{array}$ & P7 & 1 & 4 & 8 & 32 & - \\
\hline Deviations from the project & P8 & 2 & 8 & 7 & 112 & - \\
\hline
\end{tabular}

Legal provisions preventing

Malfunction-breach of duty by the participants of the construction process

P9 $\quad \begin{array}{llll}6 & 8 & 8 & 384\end{array}$

Improper exploitation of ready-made facility

$\begin{array}{lllll}\mathrm{P} 10 & 8 & 10 & 9 & 720\end{array}$

Exploitation

Lack of periodic inspection of the facility unprofessional actions of all participants

of the investment process

Controls at the construction stage of a new facility

Compliance with the inspection deadlines

Conducting regular inspections of the technical condition and regular renovation of the facility

Clearly defined rules for periodic inspection

Sanctions for failure to carry out technical inspections and renovations 
In the table, the causes of the structural failures that took place were analyzed, therefore, their severity for the victims (S) is high. It should be remembered that a structural failure is a construction accident involving the unintentional, violent destruction of a building or its parts and structural components of scaffolding, shape-forming components, sheet piling and excavation support (Gilbert et al. 2020; Anthopoulos et al. 2013; Loosemore 1999). Probability $(\mathrm{P})$ is determined based on the frequency of occurrence according to data from the General Office of Building Control (GUNB).

Additionally, the Priority Risk Number (RPN) analysis was performed graphically (Figure 9). In the literature, the limit value for the RPN = 100 is assumed. According to the assumptions of the FMEA method, if the LPR value is less than 100, it is assumed that the failure does not pose a significant threat to the process, and attention should be paid to the RPN value greater than 100. Two reasons were omitted in the analyzed data: P8. Deviations from the project $(\mathrm{RPN}=112)$ and P5. Design mistakes and errors (not detected during the design process) $(\mathrm{RPN}=160)$, the value of which is greater than 100 , but at the same time they have very low probability of occurrence $(P=2)$. That is why the causes for which RPN is greater than 240 were further analyzed, which is closely related to the analyzed topic and the collected data. Based on the conducted analyses, the authors concluded that, from the point of view of the analyzed problem, it is important to select for further analysis those causes whose value is greater than 240 . The paper focuses on the analysis of those causes that occur more frequently. The RPN values for individual causes of the structural failures are provided, and the red line marks the limit level (240). In case of the causes for which the RPN was above 240, preventive actions were suggested in Table 2. As can be seen, it concerned 7 out of 11 causes.

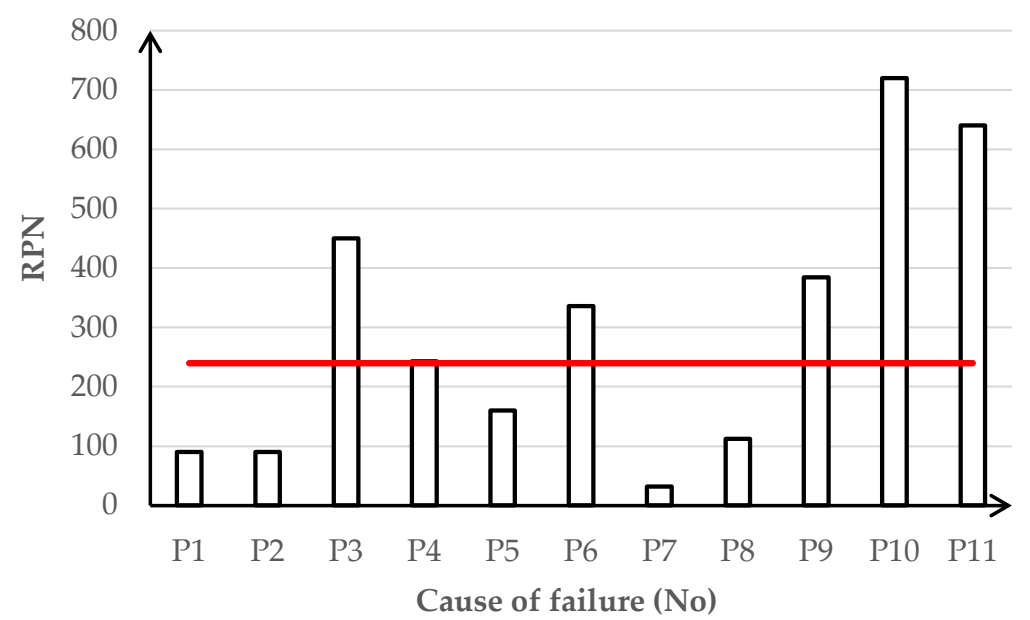

Figure 9. RPN of the structural failures caused by human error (own study).

From the analysis of the Figure 9 it can be concluded that the greatest risk of structural failure concerns two causes, e.g., P10. Improper exploitation of ready-made facility $(\mathrm{RPN}=720)$ and P11. Lack of periodic inspection of the facility $(\mathrm{RPN}=640)$. Based on the risk analysis, preventive actions were proposed for the causes with RPN above 240:

- controls at the construction stage of a new facility;

- regulations including the minimum parameters with which the material must comply;

- legal provisions preventing unprofessional actions of all participants of the investment process;

- compliance with the inspection deadlines;

- conducting regular inspections of the technical condition and regular renovation of the facility;

- clearly defined rules for periodic inspection;

- $\quad$ sanctions for failure to carry out technical inspections and renovations. 
As it is known, the owners and managers of single-family residential buildings, farm buildings and holiday houses are exempt from performing an annual periodic inspection which aims at checking the technical condition of the construction elements and installations exposed to harmful weather conditions and damaging factors occurring during the exploitation of the facility. Such a service can, of course, be ordered individually, but unfortunately it is paid. Certainly, there would be fewer such failures of these types of the constructions if the abovementioned controls were required by law.

\section{Conclusions}

The purpose of the analyses of the occurrence of the structural failures, their frequency, significance and effects, was to better understand these phenomena and their causes in order to develop ways and methods of controlling them (if not completely, at least partially). The purpose of obtaining this knowledge was to develop methods and actions that can allow to prevent structural failures or limit their influence, albeit only to a certain extent, and the effects they entail. Experiences related to the structural failures, and above all its causes, plus recording data on the condition of the facility, can provide a lot of information about the risk of a failure. This applies to both failures caused by random events and those resulting from direct human error.

From the conducted analyses it can be concluded that structural failures are most often caused by random causes. Their monitoring and analysis are very important, because despite the fact that natural phenomena are responsible for them and they are difficult to predict, their analysis makes it possible to propose some preventive actions. They result in changes to design standards, as well as implementation of long-term remedial measures, e.g., flood prevention measures.

The structural failures caused by human error are often implied by the desire to save on materials and execution works during the construction stage of a facility, as well as avoiding control, not responding to signals informing about poor technical condition. From the analysis of data obtained from the General Office of Building Control (GUNB) it can be concluded that in the five-year research period, the majority of structural failures concerned farm or livestock buildings. Failures of the residential buildings are in second place. The data analysis also showed that the most common cause of structural failures in 2015-2019 was the poor technical condition of the facility. In 2018, 35 failures were caused by this problem. In the group of errors during the construction of a new facility or the performance of other construction works in an existing facility, non-compliance with the execution technology is the most common. This cause was responsible for 20 failures in 2017. In the group of mistakes during construction of a new facility or performing other construction works, failure to comply with the technology of construction was the most common cause of failures. In 2017, it caused 20 failures at different facilities.

The aim of the analysis was to make people aware of the importance of incorrect actions, but also, and perhaps above all, the importance of negligence on the part of the participants in the construction process and subsequent users. In particular, users must be aware that any cracks or damage may result in an accident or a structural failure.

The data from the FMEA analysis showed how each cause influences the Risk Priority Number (RPN), which reflects the risk of structural failures. The RPN for P3, P4, P6, P9, P10, P11 causes varies from 243 to 720 . Their value largely depends on the severity (S), because the occurrence of structural failures usually involves enormous damage. For RPN values above 240 , preventive actions have been proposed. However, it is up to individuals to make sense of these actions. Unfortunately, we still have to deal with avoiding legal regulations, attempts to save on materials, non-compliance with lack of control or improper control. It is possible to reduce the number of structural failures by increasing the inspections of local construction supervision authorities. In order to improve the situation, it is necessary to propose amendments to the provisions of the construction law and its absolute observance.

It should be remembered that the structural failures may pose a threat to the surroundings, i.e., the natural environment and local residents. Construction companies must act in 
accordance with construction laws, the concept of sustainable development, and be socially responsible, precisely because the structural failures can cause much damage. Therefore, it is worth analyzing them in order to, if not avoid, at least minimize the probability of their occurrence. It is also important to note that people need to understand the consequences of the structural failures in order to follow generally accepted rules.

The source of the analysis (General Office of Building Control (GUNB)) does not provide financial losses related to particular types of structural failure. However, it should be emphasized that the losses in such cases are very big. In addition to the losses related to the collapse of the facility itself, there are costs related to the analysis of the causes, compensation, cleaning the area of the failure, the possible cost of rebuilding the destroyed facility, etc. There is one more important element concerning the possibility of death caused by such a failure, as the cost of human life is a human tragedy which cannot be estimated in monetary terms.

There are some limitations to the presented research. The analysis concerned a selected European country (Poland). With regard to random causes, related to, for example, natural phenomena, they do not occur very often in Poland. Most often they are heavy rainfall, floods or very strong winds. But there are countries, for example, in Southern Europe, such as Italy, where earthquakes occur, as well as countries in Asia and coastal areas where the phenomena of tsunamis or mudslides occur, which do not occur in Poland. Therefore, it would be worth carrying out similar analyses in other countries in order to identify the most common types of causes of structural failures and to propose preventive actions that would help to minimize their occurrence or their consequences.

Author Contributions: Conceptualization, A.C. and M.I.; methodology, A.C.; validation, M.I.; formal analysis, A.C.; investigation, M.I.; resources, A.C.; writing—original draft preparation, A.C. and M.I.; writing-review and editing, A.C. and M.I.; visualization, M.I. All authors have read and agreed to the published version of the manuscript.

Funding: Publication financed from statutory research of the Czestochowa University of Technology SPB-600-3016/2021.

Institutional Review Board Statement: Not applicable.

Informed Consent Statement: Not applicable.

Data Availability Statement: Research based data from the General Office of Building Control (GUNB): https:/ / www.gunb.gov.pl/ (accessed on 15 December 2020).

Conflicts of Interest: The authors declare no conflict of interest.

\section{References}

Act. 1994. Construction Act. Journal of Laws 2010: 1623.

Anaman, Kwabena Asomanin, and Charity Osei-Amponsah. 2007. Analysis of the causality links between the growth of the constructionindustry and the growth of the macro-economy in Ghana. Construction Management and Economics 25: 951-61. [CrossRef]

Anderson, Dan. 2005. Corporate Survival: The Critical Importance of Sustainability Risk Management. Lincoln: iUniverse, p. 12.

Anderson, Dan. 2007. Sustainability Risk Management as a Critical Component of Enterprise Risk Management: Global Warming-Climate Change Risks. Berlin: International Insurance Society Seminar.

Anthopoulos, Leonidas G., Efrosini Kostavara, and John-Paris Pantouvakis. 2013. An Effective Disaster Recovery Model for Construction Projects. Procedia-Social and Behavioral Sciences 74: 21-30. [CrossRef]

Aziz, Nazliatul Aniza Abdul, Norlida Abdul Manab, and Siti Norezam Othman. 2016. Sustainability risk management (SRM): An extension of enterprise risk management (ERM) concept. International Journal of Management and Sustainability 5: 1-10. [CrossRef]

Bakk, Aleksandra, and Ryszard Chmielewski. 2019. Analysis of repair works to remove the effects of structural failure after a gas explosion. MATEC Web Conference 284: 02002. [CrossRef]

Bhattacharjee, Pushparenu, Vidyut Dey, and U. K. Mandal. 2020. Risk assessment by failure mode and effects analysis (FMEA) using an interval number based logistic regression model. Safety Science 132: 104967. [CrossRef]

Bhattacharyya, Som Sekhar. 2010. A resource-centric perspective on strategic and sustainable Corporate Social Responsibility (CSR) initiatives. International Journal of Business Competition and Growth (IJBCG) 1: 62-84. [CrossRef]

Bian, Junsong, Yi Liao, Yao-Yu Wang, and Feng Tao. 2021. Analysis of firm CSR strategies. European Journal of Operational Research 290: 914-26. [CrossRef] 
Blikharskyy, Yaroslav, Nadiia Kopiika, and Jacek Selejdak. 2020. Non-uniform corrosion of steel rebar and its influence on reinforced concrete elements' reliability. Production Engineering Archives 26: 67-72. [CrossRef]

Boadu, Elijah Frimpong, Cynthia Changxin Wang, and Riza Yosia Sunindijo. 2020. Characteristics of the Construction Industry inDeveloping Countries and Its Implications for Healthand Safety: An Exploratory Study in Ghana. International Journal of Environmental Research and Public Health 17: 4110. [CrossRef] [PubMed]

Boyle, Carol, Gavin Mudd, James R. Mihelcic, Paul Anastas, Terry Collins, Patricia Culligan, Marc Edwards, Jeremy Gabe, Patricia Gallagher, Handy Susan, and et al. 2010. Delivering sustainable infrastructure that supports the urban built environment. Environmental Science \& Technology 44: 4836-40. [CrossRef]

Choguill, Charles L. 1996. Ten steps to sustainable infrastructure. Habitat International 20: 389-404. [CrossRef]

Chwistecka-Dudek, Halina. 2016. Corporate social responsibility: Supporters vs. Opponents of the concept. Forum Scientiae Oeconomia 4: 171-9.

Czajkowska, Agnieszka, and Manuela Ingaldi. 2019. Analysis of the Impact of Individual Phases in the Building Process Cycle on the Environment with Respect to the Principles of Sustainable Development. Paper presented at 2nd International Conference on the Sustainable Energy and Environmental Development (SEED'17), Kraków, Polska, November 14-17. [CrossRef]

Czajkowska, Agnieszka. 2019. Analysis of causes of structural failures of buildings using TQC tools. MATEC Web Conference 284: 08002. [CrossRef]

Deptuła, Anna Małgorzata, and Ryszard Knosala. 2015. Risk assessment of the innovative projects implementation. Management and Production Engineering Review 6: 15-16. [CrossRef]

Dziwiński, Robert. 2009. Rola przepisów prawa w kształtowaniu bezpieczeństwa obiektów budowlanych. Paper presented at Konferencja Awarie budowlane 2009, XXIV Konferencja Naukowo-Techniczna, Szczecin-Międzyzdroje, Poland, May 26-29; pp. 63-72.

Gilbert, Hinge, Rao Y. Surampalli, and Manish Kumar Goyal. 2020. Sustainable Infrastructure. In Sustainability: Fundamentals and Applications. Edited by Rao Surampalli, Tian Zhang, Manish Kumar Goyal, Satinder Brar and R. Tyagi. Hoboken: John Wiley \& Sons, Ltd., pp. 295-311. [CrossRef]

Haigh, R., D. Amaratunga, and K. Kerimanginaye. 2006. An Exploration of the Construction Industry's Role in Disaster Preparedness, Response and Recovery. Paper presented at the Construction and Building Research Conference of the Royal Institution of Chartered Surveyors University College London, London, UK, September 7-8.

Heinrich, R., R. Amhof, and L. Caduff. 2010. Sustainability Risks: Fitness Check for Executive and Supervisory Boards. Available online: https:/ / www2.eycom.ch/publications/items/board/2010_sust_risk/2010_EY_SR_e.pdf (accessed on 6 October 2013).

Ingaldi, Manuela, and Dorota Klimecka-Tatar. 2020. People's Attitude to Energy from Hydrogen-from the Point of View of Modern Energy Technologies and Social Responsibility. Energies 13: 6495. [CrossRef]

Kerzner, Harold. 2011. Recovery Project Management: Techniques and Tactics for Reversing Failing Projects. International Institute for Learning (IIL) Inc. Available online: https:/ / www.projectmanagement.com/pdf/recoverypmtechnique.pdf (accessed on 11 January 2017).

Kloosterman, Ritsche Anne, Veeneman Wijnand, and Jan Peter van der Hoek. 2020. Sustainable Societal Infrastructures: A Resilient Approach to Prevent Conflicting Claims of Drinking Water and Other Infrastructures. Sustainability 12: 785. [CrossRef]

Kong, Linghui, Sial Muhammad, Safdar Ahmad, Naveed Sehleanu, Mariana Li, Zhihui Zia-Ud-Din Malik, and Daniel Badulescu. 2021. CSR as a Potential Motivator to Shape Employees' View towards Nature for a Sustainable Workplace Environment. Sustainability 13: 1499. [CrossRef]

Lazar, Sebastjan, Dorota Klimecka-Tatar, and Obrech Matevz. 2021. Sustainability Orientationand Focus in Logistics and Supply Chains. Sustainability 13: 3280. [CrossRef]

Lindahl, Mattias. 1999. E-FMEA-A new Promising Tool for Efficient Design for Environment. Paper presented at First International Symposium on Environmentally Conscious Design and Inverse Manufacturing, Tokyo, Japan, February 1-3; pp. 734-40. [CrossRef]

Lolli, Francesco, Ishizaka Alessio, Gamberini Rita, Rimini Bianca, and Michael Messori. 2015. FlowSort-GDSS-A novel group multi-criteria decision support system for sorting problems with application to FMEA. Expert Systems with Applications 42: 6342-49. [CrossRef]

Loosemore, Martin. 1999. A grounded theory of construction crisis management. Construction Management and Economics 17: 9-19. [CrossRef]

May, G. G. 2014. Risk Analysis: Risk Analysis of Hazards in Food: An Overview. Encyclopedia of Food Safety 1: 59-64. [CrossRef]

Muzakkir, S. M., P. Lijesh, and Hirani Harish. 2015. Failure mode and effect analysis of journal Bering. International Journal of Applied Engineering Research 10: 37752-59.

Oláh, Judit, Kitukutha Nicodemus, Haddad Hossam, Pakurár Miklós, Máté Domicián, and József Popp. 2019. Achieving Sustainable E-Commerce in Environmental, Social and Economic Dimensions by Taking Possible Trade-Offs. Sustainability 11: 89. [CrossRef]

Padgett, Jamie E., Ghosh Jayadipta, and Kristina Dennemann. 2009. Sustainable Infrastructure Subjected to Multiple Threats. Paper presented at Technical Council on Lifeline Earthquake Engineering Conference (TCLEE) 2009, Oakland, CA, USA, June 28-July 1. [CrossRef]

PN-82/B-02000. Obciążenia budowli-Zasady ustalania wartości. Polish Committee for Standardization.

PN-B-02151-4:2015-06. Akustyka budowlana-Ochrona przed hałasem w budynkach-Część 4: Wymagania dotyczące warunków pogłosowych i zrozumiałości mowy w pomieszczeniach oraz wytyczne prowadzenia badań. Polish Committee for Standardization. 
PN-B-02151-5:2017-10. Akustyka budowlana-Ochrona przed hałasem w budynkach—Część 5: Wymagania dotyczące budynków mieszkalnych o podwyższonym standardzie akustycznym oraz zasady ich klasyfikacji. Polish Committee for Standardization.

PN-EN-12354-1:2017-10. Building acoustics-Estimation of acoustic performance of buildings from the performance of elements-Part 2: Impact sound insulation between rooms. Polish Committee for Standardization.

Regulation. 2003. Regulation of the Minister of Infrastructure of 3 July 2003 on the construction book. Journal of Laws 2003, No. 120, item 1134. July 3.

Regulation. 2010. Regulation of the Minister of Internal Affairs and Administration of 7 June 2010 on fire protection of buildings, other structures and areas. Journal of Laws 2010, No. 109, item 719. June 7.

Regulation. 2011. Regulation (EU) No 305/2011 of the European Parliament and of the Council of 9 March 2011 aying down harmonised conditions for the marketing of construction products and repealing Council Directive 89/106/EEC (Annex 1) (OJ L 88, 4.4.2011, pp. 5-43). March 9.

Regulation. 2019. Regulation of the Minister of Infrastructure on technical conditions to be met by buildings and their location. Journal of Laws 2019, item 1065.

Schulte, Jesko, and Sophie I. Hallstedt. 2018. Company Risk Management in Light of the Sustainability Transition. Sustainability 10: 4137. [CrossRef]

Shilu Sun, Tiantian Li, Hong Ma, Rita Yi, Man Li, Kostas Gouliamos, Jianming Zheng, Yan Han, Otilia Manta, Ubaldo Comite, Teresa Barros, and et al. 2020. Does Employee Quality Affect Corporate Social Responsibility? Evidence from China. Sustainability 12: 2692. [CrossRef]

Šnircová Jana, Fidlerová Helena, and Lucia Božiková. 2016. Sustainable Global Competitiveness Model as a New Strategic Opportunity for the Companies in Slovakia. TEM Journal 5: 241-47.

Su, Chao-Ton, Lin Hung-Chun, Teng Po-Wen, and Taho Yang. 2014. Improving the reliability of electronic paper display using FMEA and Taguchi methods: A case study. Microelectronics Reliability 54: 1369-77. [CrossRef]

Suffari, Nur Farhana Zain, Mustaffa Majid, Muhammad Khamar Tazilah, and Danial Afiq Mohd. 2019. Conceptual study of social responsibility awareness and practices among school children. International Journal of Business and Technology Management 1: 1-17.

Surówka, Marcin, Popławski Łukasz, and Helena Fidlerová. 2021. Technical Infrastructure as an Element of Sustainable Development of Rural Regions in Małopolskie Voivodeship in Poland and Trnava Region in Slovakia. Agriculture 11: 141. [CrossRef]

Szymczak-Graczyk, Anna. 2011. Obciążenie wiatrem budynków. Architectura 10: 25-32.

Tang, Zhi, and Jintong Tang. 2012. Stakeholder-firm power difference, stakeholders' CSR orientation, and SMEs' environmental performancein China. Journal of Business Venturing 27: 436-55. [CrossRef]

Thomé, Antônio Márcio Tavares, Paula Santos Ceryno, Annibal Scavarda, and Arne Remmen. 2016. Sustainable infrastructure: A review and a research agenda. Journal of Environmental Management 184: 143-56. [CrossRef]

Ulewicz, Robert, and Małgorzata Ulewicz. 2020. Problems in the Implementation of the Lean Concept in the Construction Industries. Lecture Notes in Civil Engineering 47: 495-500. [CrossRef]

Ulutaş Duman, Dilek, Giritli Heyecan, and Peter McDermott. 2016. Corporate social responsibility in construction industry: A comparative study between UK and Turkey. Built Environment Project and Asset Management 6: 218-31. [CrossRef]

United Nations General Assembly. 2015. Transforming Our world: The 2030 Agenda for Sustainable Development. A/RES/70/1. Available online: https:/ / sustainabledevelopment.un.org/content/documents/21252030\%20Agenda\%20for $\% 20$ Sustainable\% 20Development\%20web.pdf (accessed on 15 January 2021).

Wolniak, Radosław. 2019. Problems of use of FMEA method in industrial enterprise. Production Engineering Archives 23: 12-7. [CrossRef]

Wołowiec, Tomasz. 2004. Społeczna odpowiedzialność przedsiębiorstw nową formuła zarządzania. Ekonomika i Organizacja Przedsiębiorstwa 3: 3-11.

Yang, Chunsheng, Zou Yanni, Lai Pinhua, and Nan Jiang. 2015. Data mining-based methods for fault isolation with validated FMEA model ranking. Applied Intelligence 43: 913-23. [CrossRef]

Yilmaz, Ayse Kucuk, and Triant Flouris. 2010. Managing corporate sustainability: Risk management process based perspective. African Journal of Business Management 4: 162-71.

Yin, Juelin. 2017. Institutional drivers for corporate social responsibility in an emerging economy: A mixed-method study of Chinesebusiness executives. Business \& Society 56: 672-704. [CrossRef]

Zhang, Xi. 2012. Analysis on the Reason of Chinese College Students' Weakening Social Responsibility and Cultivation from Sociological Perspective. Asian Social Science 8: 132-35. [CrossRef]

Zhelykh, Vasyl, Venhryn Iryna, Kozak Khrystyna, and Stepan Shapoval. 2020. Solar collectors integrated into transparent facades. Production Engineering Archives 26: 84-7. [CrossRef] 